\title{
Trans-10, cis-12-conjugated linoleic acid reduces the hepatic triacylglycerol content and the leptin mRNA level in adipose tissue in obese Zucker fa/fa rats
}

\author{
Oddrun A. Gudbrandsen ${ }^{1}$, Enrique Rodríguez ${ }^{2}$, Hege Wergedahl $^{1}$, Sverre Mørk ${ }^{3}$, Janne E. Reseland ${ }^{4}$, \\ Jon Skorve ${ }^{1}$, Andreu Palou ${ }^{2}$ and Rolf K. Berge ${ }^{1}$ \\ ${ }^{1}$ Institute of Medicine, Haukeland University Hospital, University of Bergen, N-5021 Bergen, Norway \\ ${ }^{2}$ Laboratory of Molecular Biology, Nutrition and Biotechnology (Nutrigenomics), University of the Balearic Islands (UIB), CIBER \\ Fisiopatología Obesidad y Nutrición (CB06/03), Instituto de Salud Carlos III, 07122 Palma de Mallorca, Spain \\ ${ }^{3}$ Department of Pathology, Gade Institute, Haukeland University Hospital, University of Bergen, N-5021 Bergen, Norway \\ ${ }^{4}$ Department of Nutrition, Faculty of Medicine, Institute of Basic Medical Sciences, University of Oslo, POB 1046, N-0316 Oslo, \\ Norway \\ (Received 25 May 2008 - Revised 5 January 2009 - Accepted 9 January 2009 - First published online 19 March 2009)
}

Conjugated linoleic acid (CLA) isomers have been reported to reduce body weight and beneficially affect glucose metabolism in animals, but the results are inconsistent and seem to depend on animal model and type of CLA isomer. In the present study, feeding male Zucker fa/fa rats diets supplemented with $1 \%$ trans-10, cis-12-CLA for $10 \mathrm{~d}$ reduced the liver TAG content without improving the overall adiposity, and enhanced hepatic mitochondrial and peroxisomal $\beta$-oxidation. The increased carnitine palmitoyltransferase (CPT)-I activity and mRNA level as well as the increased $n-3: n-6$ PUFA ratio in liver suggest that trans-10, cis-12-CLA increased the hepatic $\beta$-oxidation by stimulation of PPAR $\alpha$. The reduced hepatic TAG content may be partly due to lower activity of stearoyl-CoA desaturase, as the ratios of 18:1n-9:18:0 and 16:1n-7:16:0 were reduced in liver. Trans-10, cis-12-CLA increased the CPT-I mRNA in retroperitoneal white adipose tissue (WAT), and increased uncoupling protein-2 mRNA in epididymal and inguinal WAT depots. Leptin mRNA level was decreased in all examined WAT depots, implying reduced insulin sensitivity. The resistin mRNA level was increased in all WAT depots, whereas adiponectin mRNA was reduced in inguinal and retroperitoneal WAT. The present results suggest that dietary supplementation with trans-10, cis-12-CLA may increase the catabolism of lipids in liver and adipose tissue. Moreover, we provide new data suggesting that trans-10, cis-12-CLA modulates the expression of resistin and adiponectin inversely in adipose tissue. Hence, the present results suggest that trans-10, cis-12-CLA may have some beneficial effects on lipid metabolism and adiposity but possibly reduces insulin sensitivity.

Conjugated linoleic acid: Hepatic steatosis: $\beta$-Oxidation: Obese Zucker rats

Conjugated linoleic acid (CLA) consists of a group of positional and geometrical isomers of octadecadienoic acid. Dietary CLA is usually a mixture of various CLA isomers and has received increasing attention during the last decades due to suggested health benefits in rodents, including reduced risk of cancer, atherosclerosis, obesity and diabetes, and stimulation of the immune system ${ }^{(1)}$. Ruminant milk and meat are the major natural sources of CLA, and the CLA content is stable under normal cooking and storage conditions ${ }^{(2)}$. In milk and meat from ruminants, the most prevalent isomer of CLA is cis-9, trans-11-CLA followed by trans-7, cis-9-CLA, and only minor amounts of trans-10, cis-12-CLA are found $^{(3,4)}$. This is in contrast with synthetically prepared CLA isomer mixtures, which often contains mainly cis-9, trans-11-CLA and trans-10, cis-12-CLA ${ }^{(2)}$. Recent evidence suggests that the health effects of CLA relate to the type of isomer $^{(5-7)}$, and especially the isomers cis-9, trans-11-CLA and trans-10, cis-12-CLA are believed to be responsible for the biological properties attributed to CLA mixtures, where trans-10, cis-12-CLA may play a role in the regulation of body weight and glucose homeostasis ${ }^{(8-11)}$.

The ability of trans-10, cis-12-CLA to reduce adipose tissue mass has been linked to increased lipolysis and fatty acid oxidation $^{(12,13)}$, increased energy expenditure ${ }^{(14)}$, decreased lipogenesis $^{(15)}$ and reduced adipogenesis ${ }^{(16)}$ as well as increased apoptosis $^{(10)}$. Enhanced energy expenditure in response to dietary CLA does not seem to be associated with changes in the expression of uncoupling protein (UCP)- 1 in brown adipose tissue ${ }^{(17)}$, but increased expression of UCP-2 have been observed in white adipose tissue (WAT) of animals fed $\mathrm{CLA}^{(9,18)}$. At the present time there are only a few studies on isomer-specific effects of CLA on $\mathrm{UCP}^{(6,19)}$.

Abbreviations: CLA, conjugated linoleic acid; CPT, carnitine palmitoyltransferase; eWAT, epididymal white adipose tissue; HMG, 3-hydroxy-3-methylglutaryl; iWAT, inguinal white adipose tissue; L-CPT, liver carnitine palmitoyltransferase; rWAT, retroperitoneal white adipose tissue; Tris, 2-amino-2-hydroxymethyl-propane-1, 3-diol; UCP, uncoupling protein; WAT, white adipose tissue.

* Corresponding author: Dr Oddrun A. Gudbrandsen, fax +47 55973115, email oddrun.gudbrandsen@med.uib.no 
It has been demonstrated that glucose tolerance is improved in animal models of insulin resistance such as obese Zucker rats $^{(11)}$ and Zucker diabetic fatty rats ${ }^{(9)}$ after trans-10, cis-12 feeding, but increased insulin resistance after dietary supplementation with this CLA isomer has been reported in normal and obese mice ${ }^{(18,20)}$ and humans ${ }^{(21)}$. The adipokines resistin and adiponectin have been studied due to their potential roles in regulating insulin resistance and glucose homeostasis also in obese subjects ${ }^{(22-26)}$. Adiponectin enhances fatty acid oxidation in muscle and inhibits hepatic gluconeogenesis, promoting reduced plasma levels of NEFA, TAG and glucose resulting in improved insulin sensitivity $^{(27-29)}$, whereas elevated plasma resistin levels may cause insulin resistance ${ }^{(25)}$.

The aim of the present study was to study the response to a specific CLA isomer (trans-10, cis-12-CLA) in WAT and liver by measuring fatty acid $\beta$-oxidation and synthesis, and to study the effect of this isomer on the expression of genes involved in the regulation of lipid metabolism and energy balance. In addition, we wanted to characterise the effects of trans-10, cis-12-CLA on glucose homeostasis and study whether these effects are related to the modulation of adiponectin and resistin gene expression. In the present study we used obese Zucker fa/fa rats, which have a null mutation of the leptin receptor gene and have been extensively studied as a model for obesity and diabetes in humans.

\section{Materials and methods}

\section{Animals and diets}

Male obese Zucker Crl:(ZUC)/FaBR (fa/fa) rats from Charles River Laboratories (Sulzfeld, Germany), aged 5 weeks, were divided into two experimental groups of six rats each with comparable mean body weight. The rats were housed individually in metabolism cages in a room maintained at a $12 \mathrm{~h}$ light-dark cycle (light from 07.00 to 19.00 hours) and a constant temperature of $20 \pm 3^{\circ} \mathrm{C}$ and relative humidity of $65 \pm 15 \%$. The rats were acclimatised under these conditions before the start of the experiment.

The rats were fed diets containing $20 \%$ (by weight) casein sodium salt from bovine milk (C-8654; Sigma-Aldrich Norway AS, Oslo, Norway). To the diets were added $10 \%$ (by weight) commercial soya oil (control group) or $9 \%$ (by weight) commercial soya oil and $1 \%$ (by weight) trans-10, cis-12-CLA $(97.15 \%$ non-esterified trans-10, cis-12-CLA, kindly provided by Natural ASA, Hovdebygda, Norway) (trans-10, cis-12-CLA group). To all diets were added $1 \%$ of AIN-93VX Vitamin mixture (Dyets Inc., Bethlehem, PA, USA), $3 \%$ of AIN-93G Mineral mixture (Dyets Inc.) and $0.2 \%$ choline hydrogen tartrate (Merck, Darmstadt, Germany). Table 1 gives an overview of the experimental diets. The rats were fed these diets for $10 \mathrm{~d}$. All rats had free access to tap water and feed (ad libitum).

At the end of the feeding period, under non-fasting conditions, the rats were anaesthetised with a $1: 1$ mixture of Hypnorm $^{\mathrm{TM}}$ (fentanyl citrate $(0 \cdot 315 \mathrm{mg} / \mathrm{ml})$ and fluanisone $(10 \mathrm{mg} / \mathrm{ml})$; Janssen Pharmaceutica, Beerse, Belgium) and Dormicum $^{\circledR}$ (midazolam $(5 \mathrm{mg} / \mathrm{ml})$; F. Hoffmann-La Roche AG, Basel, Switzerland) injected subcutaneously. Blood was drawn directly from the heart using a syringe containing
Table 1. Composition of the experimental diets ( $\mathrm{g} / \mathrm{kg}$ diet)

\begin{tabular}{lcc}
\hline & Control & Trans-10, cis-12-CLA \\
\hline Soya oil $^{*}$ & 100 & 90 \\
Trans-10, cis-12-CLA $\dagger_{\text {Casein } \ddagger}$ & - & 10 \\
Dextrin & 218 & 218 \\
Cellulose & 510 & 510 \\
Sucrose & 20 & 20 \\
Vitamins§ & 100 & 100 \\
Minerals\| & 10 & 10 \\
Choline & 30 & 30 \\
& 2 & 2
\end{tabular}

CLA, conjugated linoleic acid.

* Fatty acid composition of the soya oil (mean of two measurements, deviation less than $3 \%)(g / 100 \mathrm{~g}$ fat): $18: 2 n-6,55 \cdot 9 ; 18: 1 n-9,21 \cdot 4 ; 16: 0,11 \cdot 4 ; 18: 3 n-3,5 \cdot 8$; $18: 0,3 \cdot 3 ; 18: 1 n-7,1.6$.

† Trans-10, cis-12-CLA contained $97.15 \%$ non-esterified trans-10, cis-12-CLA (Natural ASA, Hovdebygda, Norway).

$\ddagger$ Casein ( $\mathrm{g} / \mathrm{kg}$ diet): fat, 9.8 ; ash, 31 . The casein protein contained $91.9 \%$ crude protein.

§ AIN-93VX; Dyets Inc., Bethlehem, PA, USA

IIIN-93G; Dyets Inc., Bethlehem, PA, USA.

I Choline hydrogen tartrate (Merck, Darmstadt, Germany)

heparin. Epididymal WAT (eWAT), visceral retroperitoneal WAT (rWAT) and subcutaneous inguinal WAT (iWAT) and liver were dissected out and weighed.

Plasma, WAT depots and a small piece of liver were frozen in liquid $\mathrm{N}_{2}$ and stored at $-85^{\circ} \mathrm{C}$ until analysis. The rest of the liver was kept on ice for subcellular fractionation and further analysis later the same day. The protocol was approved by the Norwegian State Board of Biological Experiments with Living Animals.

\section{In vitro assays}

Homogenisation and subcellular fractionation of the livers were performed as previously described ${ }^{(30)}$. Rat livers were homogenised individually in ice-cold sucrose solution (0.25 M-sucrose in $10 \mathrm{~mm}$-HEPES buffer ( $\mathrm{pH} \mathrm{7.4)} \mathrm{and} 1 \mathrm{mM}-$ EDTA) using a Potter-Elvehjem homogeniser. The procedures were performed at $0-4{ }^{\circ} \mathrm{C}$. The fractions were either used immediately for measurements of mitochondrial $\beta$-oxidation and carnitine palmitoyltransferase (CPT)-I activities, or stored at $-85^{\circ} \mathrm{C}$ for subsequent analysis. Protein was measured with the BioRad protein assay kit (BioRad, Richmond, CA, USA) using bovine serum albumin as the standard. The enzymic activities were analysed using two identical parallels for each sample, using the assays described below.

Palmitoyl-CoA (without or with $12 \mu \mathrm{M}$-malonyl-CoA added before the start of the reaction) and palmitoyl-L-carnitine oxidation were measured in the mitochondrial fraction as acid-soluble products ${ }^{(31)}$. The assay medium contained 12 mM-HEPES buffer ( $\mathrm{pH} 7 \cdot 3$ ), $11 \mathrm{mM}-\mathrm{MgCl}_{2}, 12 \mathrm{mM}$-dithiothreitol, 5.6 mM-ADP, 0.2 mM-NAD ${ }^{+}$, 0.6 mM-EDTA, $60 \mathrm{~mm}-$ $\mathrm{KCl}$, antimycin $\mathrm{A}(1 \mathrm{pg} / \mathrm{ml})$ and $1.0-1.2 \mathrm{mg}$ protein from the mitochondrial fraction. Palmitoyl-L-carnitine oxidation was measured with $80 \mu \mathrm{M}-\left[1-{ }^{14} \mathrm{C}\right]$ palmitoyl-L-carnitine and the palmitoyl-CoA oxidation was measured with $40 \mathrm{pm}$-palmitoylCoA supplemented with $1 \mathrm{mM}-\mathrm{L}$-carnitine. Cyanide-sensitive fatty acid oxidation was measured in the presence of $1 \mathrm{mM}-\mathrm{KCN}$. After incubation for $120-240 \mathrm{~s}$ at $30^{\circ} \mathrm{C}$, oxidation was stopped by the addition of $25 \mu$ l fatty acid-free bovine 
serum albumin $(100 \mathrm{mg} / \mathrm{ml})$ followed by $150 \mu \mathrm{l} 1.5 \mathrm{M}-\mathrm{KOH}$ and $500 \mu \mathrm{l} 4 \mathrm{M}-\mathrm{HClO}_{4}$. After centrifugation, the protein- and fatty acid-free supernatant fraction was assayed for radioactivity using a WinSpectral ${ }^{\mathrm{TM}} 1414$ Liquid Scintillator Counter spectrometer (PerkinElmer (formerly Wallac), Waltham, MA, USA).

CPT-I and CPT-II activities were measured in the mitochondrial fraction $^{(32)}$. The assay for CPT-I contained $20 \mathrm{mM}-$ HEPES， $70 \mathrm{~mm}-\mathrm{KCl} ， 5 \mathrm{~mm}-\mathrm{KCN}, 100 \mu \mathrm{M}$-palmitoyl-CoA, $10 \mathrm{mg}$ bovine serum albumin/ml and $180 \mu \mathrm{g}$ hepatic tissue protein $/ \mathrm{ml}$, and $\mathrm{pH}$ was adjusted to $7 \cdot 5$. The reaction was started by adding $200 \mu \mathrm{M}$-[methyl- $\left.{ }^{14} \mathrm{C}\right]-\mathrm{L}$-carnitine $(200 \mathrm{cpm} /$ nmol). When included, malonyl-CoA was added before the start of the reaction. Assay conditions for CPT-II were identical, except that bovine serum albumin was omitted and $0.01 \%$ Triton X-100 was included. The radioactivity was determined using the WinSpectral ${ }^{\mathrm{TM}} 1414$ Liquid Scintillator Counter spectrometer (Wallac).

Malonyl-CoA decarboxylase activity was measured in the liver post-nuclear fraction ${ }^{(33)}$. A reaction mixture containing 0.1 M-2-amino-2-hydroxymethyl-propane-1,3-diol (Tris)- $\mathrm{HCl}$ buffer ( $\mathrm{pH} 8.0), \quad 0.5 \mathrm{~mm}$-dithiothreitol, $10 \mathrm{~mm}$-L-malate, $0.5 \mathrm{~mm}-\mathrm{NAD}^{+}, 40 \mu \mathrm{M}$-rotenone and $1.4 \mu \mathrm{g}$ malate dehydrogenase $\left(1.7\right.$ units) was pre-incubated for $7 \mathrm{~min}$ at $37^{\circ} \mathrm{C}$ after which $10 \mu \mathrm{g}$ citrate synthase was added. After $1 \mathrm{~min}$ the reaction was initiated by the addition of $0.3 \mathrm{~mm}-$ malonyl-CoA and about $35 \mu \mathrm{g}$ or $170 \mu \mathrm{g}$ frozen/thawed mitochondrial or cytosolic fraction protein respectively before citrate synthase was assayed using a Varian 2300 spectrophotometer (Varian Inc., Palo Alto, CA, USA).

Fatty acyl-CoA oxidase activity was measured in the peroxisomal fraction by the coupled assay described by Small et al. ${ }^{(34)}$. The spectrophotometric assay of acyl-CoA oxidase was based on the determination of $\mathrm{H}_{2} \mathrm{O}_{2}$ production, which was coupled to the oxidation of leuco-dichlorofluorescein in a reaction catalysed by exogenous peroxidase. The production of $\mathrm{H}_{2} \mathrm{O}_{2}$ was measured by monitoring the increase in dichlorofluorescein absorbance in the presence of palmitoyl-CoA using a Varian 2300 spectrophotometer.

3-Hydroxy-3-methylglutaryl (HMG)-CoA synthase was measured spectrophotometrically in the mitochondrial fraction $^{(35)}$ in a reaction mixture containing $20 \mathrm{pmol}$ Tris- $\mathrm{HCl}$ buffer (pH 8.0), 20 nmol EDTA, $40 \mathrm{nmol}$ [1- or $2-{ }^{14} \mathrm{C}$ ]acetylCoA $\left(2 \times 10^{6} \mathrm{cpm} / \mu \mathrm{mol}\right), 10 \mathrm{nmol}$ acetoacetyl-CoA, and from $0 \cdot 1$ to $1 \cdot 0$ milliunits of HMG-CoA synthase. The reaction was initiated by the addition of $\left[{ }^{14} \mathrm{C}\right]$ acetyl-CoA to the reaction mixture. Samples were transferred to glass vials containing $0.1 \mathrm{ml}$ of $6 \mathrm{M}-\mathrm{HCl}$, and the acidified sample was dried. Water and liquid scintillator were added and non-volatile ${ }^{14} \mathrm{C}$ activity (as $\left[{ }^{14} \mathrm{C}\right] \mathrm{HMG}-\mathrm{CoA}$ plus $3-\left[{ }^{14} \mathrm{C}\right]$ methylglutaconyl-CoA) was determined using the WinSpectral ${ }^{\text {TM }} 1414$ Liquid Scintillator Counter spectrometer (Wallac).

Acetyl-CoA carboxylase activity was determined in the cytosolic fraction by measuring the amount of $\mathrm{NaH}^{14} \mathrm{CO}_{3}$ incorporated into malonyl-CoA ${ }^{(36)}$. The pre-incubated enzyme was added to an assay mixture containing $50 \mathrm{~mm}-$

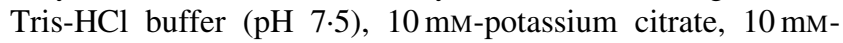
$\mathrm{MgCl}_{2}, 3.75 \mathrm{~mm}$-glutathione, $0.75 \mathrm{mg}$ bovine serum albumin per ml, $3.75 \mathrm{~mm}$-ATP, $0.125 \mathrm{mM}$-acetyl-CoA and $12.5 \mathrm{mM}$ $\mathrm{NaH}^{14} \mathrm{CO}_{3}$. After incubation for $10 \mathrm{~min}$ at $37^{\circ} \mathrm{C}$, the reaction was terminated with $0.2 \mathrm{ml} 5 \mathrm{M}-\mathrm{HCl}$. After centrifugation for
$10 \mathrm{~min}$ at $1500 \mathrm{~g}$, a sample of the supernatant fraction was dried in a counting vial, and OptiPhase HiSafe 3 (Perkin Elmer) scintillator solution was added before the radioactivity was determined using the WinSpectral ${ }^{\mathrm{TM}} 1414$ Liquid Scintillator Counter spectrometer (Wallac).

Fatty acid synthase activity was measured in the cytosolic fraction $^{(37)}$ and modified according to Skorve et al. ${ }^{(38)}$. The assay mix contained $100 \mu \mathrm{mol}$ potassium phosphate, $3 \mu \mathrm{mol}$ $\mathrm{Na}_{2}$ EDTA, $19 \mathrm{nmol}$ acetyl-CoA and $40 \mathrm{nmol}\left[{ }^{14} \mathrm{C}\right]$ acetylCoA. The reaction was started by adding $300 \mu \mathrm{M}-\mathrm{NADPH}$ and pre-incubated enzyme fraction $(100 \mu \mathrm{g}$ proteins) and run for $6 \mathrm{~min}$ at $37^{\circ} \mathrm{C}$. The reaction was stopped by adding $30 \mu \mathrm{l} 60 \%$ perchloric acid, and the mixture was diluted with ethanol. Fatty acids were extracted with petroleum ether and the residues were dissolved in pentane. Samples were counted by using the WinSpectral ${ }^{\mathrm{TM}} 1414$ Liquid Scintillator Counter $^{\mathrm{T}}$ spectrometer (Wallac).

Glycerol-3-phosphate acyl transferase activity was assayed at $30^{\circ} \mathrm{C}$ in the mitochondrial fraction ${ }^{(39)}$, in an assay mix containing $120 \mathrm{~mm}-\mathrm{KCl}, 50 \mathrm{~mm}-\mathrm{Tris}-\mathrm{HCl}$ buffer ( $\mathrm{pH} 7 \cdot 4$ ), L-[U- $\left.{ }^{14} \mathrm{C}\right]$ glycerol 3-phosphate, $65 \mu \mathrm{M}$-palmitoyl CoA, $0.7 \mathrm{~mm}$-dithiothreitol, L-glycerol 3-phosphate and $6 \mathrm{mg}$ bovine serum albumin. The reaction was initiated with $0.1 \mathrm{ml}$ of mitochondrial fraction and performed for $3 \mathrm{~min}$. The reaction was terminated with $2 \mathrm{ml}$ water-saturated butanol and radioactive incorporation into butanol-soluble products before counting

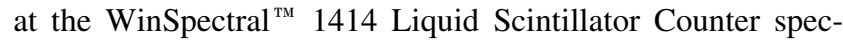
trometer (Wallac).

\section{Malonyl-co-enzyme-A}

The malonyl-CoA concentration in liver was measured by reversed-phase HPLC ${ }^{(40)}$. In brief, frozen liver was homogenised in ice-cold $1.4 \mathrm{M}-\mathrm{HClO}_{4}$ and $2 \mathrm{mM}$-D-dithiothreitol to obtain $10 \%(\mathrm{w} / \mathrm{v})$ homogenate, and centrifuged at $12000 \mathrm{~g}$ for $1 \mathrm{~min}$. Then $122 \mu \mathrm{l}$ ice-cold $3 \mathrm{M}-\mathrm{K}_{2} \mathrm{CO}_{3}$ with $0 \cdot 5 \mathrm{M}$-triethanolamine was added to $500 \mu \mathrm{l}$ of the supernatant fraction. After $10 \mathrm{~min}$ on ice, the solution was centrifuged at $12000 \mathrm{~g}$ for $1 \mathrm{~min}$ at $4^{\circ} \mathrm{C}$. Then $40 \mu \mathrm{l}$ of the supernatant fraction was injected onto the HPLC column.

\section{Lipids and fatty acid composition}

Plasma and liver lipids were measured enzymically on the Technicon Axon system (Miles, Tarrytown, NY, USA) using the following kits: TAG kit (Bayer, Tarrytown, NY, USA), total cholesterol (Bayer), NEFA (NEFA C; Wako Chemicals, Dalton, OH, USA) and phospholipids (PAP 150; bioMérieux, Lyon, France). The hepatic lipids were extracted using a mixture of chloroform and methanol $^{(41)}$, and the samples were evaporated under $\mathrm{N}_{2}$ and re-dissolved in isopropanol before analysis.

The lipids were extracted from the liver samples using chloroform and methanol ${ }^{(41)}$. The samples were added $0.2 \mathrm{M}-\mathrm{KOH}$ in ethanol and incubated at $40^{\circ} \mathrm{C}$ for $90 \mathrm{~min}$ in order to obtain NEFA. Water was added to the samples before they were washed twice with hexane. To the samples was added $6 \mathrm{M}-\mathrm{HCl}$, and the fatty acids were extracted by hexane and transferred to new tubes. After evaporation, $14 \% \mathrm{BF}_{3}-$ methanol was added, and the samples were allowed to react for $30 \mathrm{~min}$ at room temperature to obtain methyl esters before the mixture was neutralised with $2 \% \mathrm{KHCO}_{3}$. 
The methyl esters were extracted by hexane before they were analysed on a GC8000 Top gas chromatograph (Thermo Fisher (formerly Carlo Erba Instruments), Milan, Italy), equipped with a flame ionisation detector and a capillary column coated with a highly polar SP2340 phase (Supelco Inc., Bellefonte, PA, USA). The methyl esters were identified by comparison with known standards (Larodan Fine Chemicals, Malmø, Sweden). Quantification of the fatty acids was performed using the Chrom-Card A/D 1.0 chromatography station (Thermo Fisher) by comparison with an internal standard (heneicosanoic acid).

\section{Glucose in plasma}

Plasma glucose was measured enzymically on the Technicon Axon system (Miles, Tarrytown, NY, USA) using the Gluco-quant kit (Roche, Mannheim, Germany).

\section{Oil red $O$ staining of liver}

In order to study neutral fat deposits, $10 \mu \mathrm{m}$ frozen sections of the livers were cut on a Leitz cryostat 1720 (Leitz, Wetzlar, Germany) and collected on uncoated glass slides. The sections were fixed in $10 \%$ formaldehyde solution diluted in PBS at room temperature for $10 \mathrm{~min}$, then rinsed three times in distilled water. The sections were stained with oil red $\mathrm{O}$ (Sigma, St Louis, MO, USA) for $10 \mathrm{~min}$ at room temperature, then rinsed three times in distilled water and dipped in $60 \%$ ethyl alcohol to remove excess stain. The sections were then rinsed three times in distilled water, counter-stained with haematoxylin for $10 \mathrm{~min}$, rinsed three times in distilled water and sealed with cover slips.

Microphotographs were taken with a Leica DM6000B light microscope with digital camera (Leica Microsystems, Heerbrugg, Switzerland). The area of liver for each measurement was $1180000 \mu^{2}$. To analyse the whole liver lobule we chose one image with the central vein in the centre, and another image was centred on the portal tract for each rat. The quantification of the lipid droplets was performed using the analySIS soft imaging system to measure the area of positive oil red $\mathrm{O}$ staining. Images were coded for blinding.

\section{Plasma leptin, adiponectin and insulin}

Leptin, adiponectin and insulin in plasma were quantified by competitive RIA (Linco Research Inc., St Charles, MO, USA).

\section{RNA isolation}

Total RNA was isolated from $200-300 \mathrm{mg}$ eWAT, iWAT and rWAT or $50 \mathrm{mg}$ liver using TRIzol reagent (Life Technologies, Norway) and according to the manufacturer's instructions.

\section{Reverse transcriptase PCR analysis}

To quantify the mRNA levels of CPT-I in liver as well as liver isoform L-CPT-I and adiponectin in different WAT depots, a semi-quantitative RT-PCR assay was developed, using the housekeeping gene $\beta$-actin as an internal control ${ }^{(42)}$.
In brief, $0.5 \mu \mathrm{g}$ total RNA was denatured at $65^{\circ} \mathrm{C}$ for $10 \mathrm{~min}$ and reversely transcribed in the presence of $50 \mathrm{pmol}$ of random primers, using MuLV RT (Perkin-Elmer, Madrid, Spain) at $42^{\circ} \mathrm{C}$ for $30 \mathrm{~min}$ in a Perkin-Elmer 9700 Thermal Cycler. After the reaction, the RT medium was added to a PCR mix containing Taq DNA polymerase (Promega, Lyon, France) and an appropriate amount of specific pairs of primers. The reaction mixture was first heated to $95^{\circ} \mathrm{C}$ for 2 min to denature the cDNA. This was followed by twentytwo to twenty-eight cycles of denaturation at $95^{\circ} \mathrm{C}$ for $15 \mathrm{~s}$, annealing at $56-58^{\circ} \mathrm{C}$ for $15 \mathrm{~s}$ and extension at $72^{\circ} \mathrm{C}$ for $30 \mathrm{~s}$, with an additional extension at $72^{\circ} \mathrm{C}$ for $7 \mathrm{~min}$ after the last cycle. Sequences of the sense and antisense oligonucleotides were as follows: $5^{\prime}$-GCT CGC ACA TTA CAA GGA CAT- $3^{\prime}$ and $5^{\prime}$-TGG ACA CCA CAT AGA GGC AG- $3^{\prime}$ for L-CPT-I; 5'-GCT CAG GAT GCT ACT GTT G-3' and $5^{\prime}$ TCT CAC CCT TAG GAC CAA G-3' for adiponectin; $5^{\prime}$ ACG GGC ATT GTG ATG GAC TC- $3^{\prime}$ and $5^{\prime}$-GTG GTG GTG AAG CTG TAG CC- $3^{\prime}$ for $\beta$-actin. These primers were derived from the sequences of the corresponding genes and cDNA. Amplification products had the expected sizes of 268, 241 and $160 \mathrm{bp}$ for CPT-I, adiponectin and $\beta$-actin, respectively. The PCR products were separated in $2 \%$ agarose gel (MS-8; Pronadisa, Madrid, Spain) in $0.5 \times$ Tris-borate EDTA buffer, stained with ethidium bromide and visualised by an image recording system (Gelprinter, TDI, Madrid, Spain). The densities of the target bands were then quantified using an image processing and analysing program (ID Image Analysis, Kodak, Rochester, NY, USA).

\section{Northern blot analysis}

Total RNA $(25 \mu \mathrm{g})$ from liver or WAT were denatured with formamide-formaldehyde, resolved by agarose gel electrophoresis, transferred to a Hybond nylon membrane and fixed with UV light ${ }^{(43)}$. UCP2 mRNA, leptin mRNA, resistin mRNA and 18S rRNA as internal control, were analysed sequentially on the same membrane, in the above-mentioned order, by a chemiluminescence procedure based on the use of synthetic mouse-specific antisense oligonucleotide probes end-labelled with digoxigenin, essentially as in the protocols provided by Roche (Barcelona, Spain). The technique was first described by Trayhurn et al. in $1994^{(44)}$. In short, fixed membranes were pre-hybridised at $42^{\circ} \mathrm{C}$ for $1 \mathrm{~h}$ in DIG-Easy $\mathrm{Hyb}^{\mathrm{TM}}$, and then hybridised with the corresponding oligonucleotide probe in DIG-Easy $\mathrm{Hyb}^{\mathrm{TM}}$ at $42^{\circ} \mathrm{C}$ overnight. The following probes were used: UCP2, $5^{\prime}$-GGC AGA GTT CAT GTA TCT CGT CTT GAC CAC-3'; leptin, 5'-GGT CTG AGG CAG GGA GCA GCT CTT GGA GAA GGC-3'; resistin, 5'-TCC CAC GAG CCA CAG GCA GAG CCA CAG GAG CAGC-3'; 18S rRNA, 5'-CGC CTG CTG CCT TCC TTG GAT GTG GTA GCC G-3'. The membranes were blocked and incubated first with an anti-digoxigenin-alkaline phosphatase conjugate and then with the chemiluminescent substrate CDP-Star ${ }^{\mathrm{TM}}$. Finally, membranes were exposed to Hyperfilm ECL ${ }^{\mathrm{TM}}$ (Amersham, Barcelona, Spain). Bands in films were analysed by scanner photodensitometry and quantified using the ID Image Analysis software (Kodak). Stripping in between analysis was performed by exposing the membranes to boiling $0 \cdot 1 \%$ SDS. 


\section{Statistical analysis}

All data in tables and figures are presented as mean values with their standard errors. The body weights of the rats fed CLA or control diets were compared using a non-parametric test (Mann-Whitney rank). All other results from trans-10, cis-12-CLA-fed rats and rats fed the control diet were compared pair-wise using a two-sample variance Student's $t$ test (two-tailed distribution), with level of statistical significance set at $P<0 \cdot 05$.

\section{Results}

Growth, liver weight and white adipose tissue depot weights

The body weight before the experiment started (day 0) was similar between the rats receiving the $1 \%$ trans-10, cis-12CLA-supplemented diet or the control diet (127 (SEM 14) and 116 (SEM 10) g, respectively) (Fig. 1(a)). No significant differences in the body weights were seen between the feeding groups after $10 \mathrm{~d}$ (Fig. 1(a)). No significant effects were seen on the relative weight of liver or eWAT, rWAT and iWAT depots (Table 2). Also, no significant changes were seen in the absolute weights of these WAT depots (data not shown).

Feed intake was similar in rats fed the trans-10, cis-12-CLA or control diets for the first $2 \mathrm{~d}$ of the experiment, but feed intake was markedly lower for the rest of the experiment for the trans-10, cis-12 CLA-fed rats (Fig. 1(b)).

\section{Liver lipids and hepatic fatty acid metabolism}

To investigate whether trans-10, cis-12-CLA could affect hepatic lipid metabolism after only $10 \mathrm{~d}$ feeding, we stained
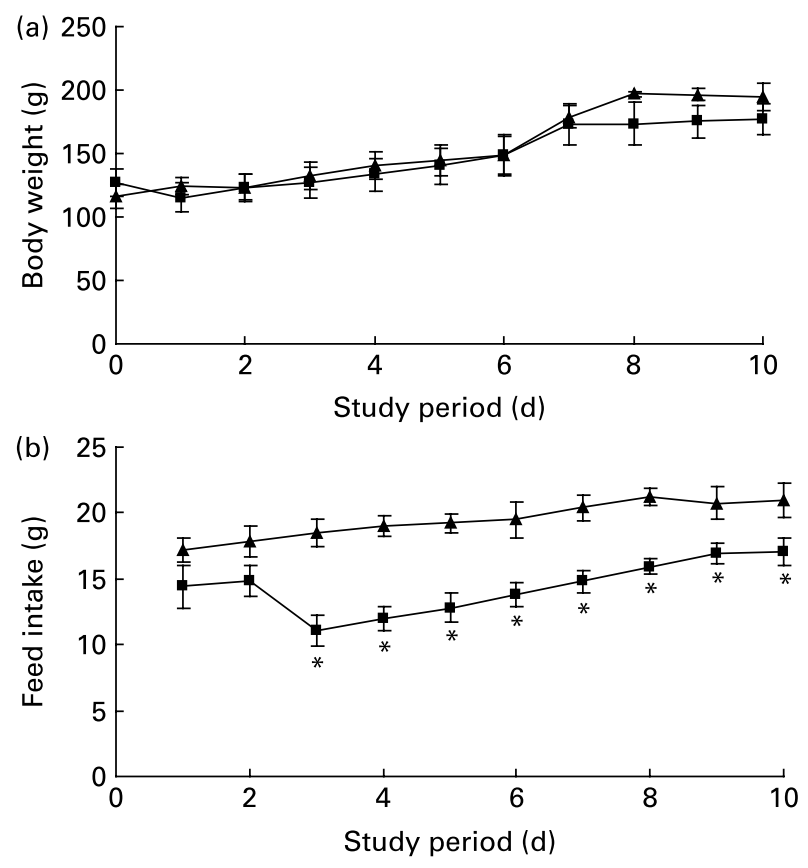

Fig. 1. Body weight (a) and feed intake (b) curves for obese Zucker rats fed a control diet $(-\boldsymbol{\Delta}-)$ or a diet containing $1 \%$ trans-10, cis-12-conjugated linoleic acid (-口-) for $10 \mathrm{~d}$. Values are means, with standard errors represented by vertical bars $(n 6)$. * Mean value was significantly different from that of the control group $(P<0.05)$. the liver pieces from all rats with oil red $\mathrm{O}$ and measured the content of neutral lipids. To analyse the whole liver lobule we chose one image with the portal tract in the centre (Fig. 2), and another centred on the central vein (data not shown). The lipid droplets in livers from rats fed trans-10, cis-12-CLA were smaller as compared with control livers, and the total content of neutral lipids was markedly lower (Fig. 2). The hepatic TAG level was markedly decreased after administration of trans-10, cis-12-CLA (Fig. 2), but no changes were observed for the levels of cholesterol, phospholipids and NEFA (data not shown).

To gain insight to the mechanism by which trans-10, cis-12-CLA decreased the level of hepatic TAG, we measured the capacity of mitochondrial and peroxisomal $\beta$-oxidation as well as lipogenesis and TAG biosynthesis in the liver. Mitochondrial $\beta$-oxidation, measured by using palmitoylCoA or palmitoyl-L-carnitine as substrates, was markedly higher in the liver from rats fed trans-10, cis-12-CLA (Figs. 3(a) and (b), respectively). This was accompanied by increased activities of CPT-I (Fig. 3(c)), the rate-limiting enzyme involved in the mitochondrial uptake of fatty acids, and of CPT-II (Fig. 3(d)). The expression of CPT-I mRNA was also increased in liver after trans-10, cis-12-CLA feeding (Fig. 3(e)). In addition, hepatic activity of mitochondrial HMG-CoA synthase, the rate-limiting enzyme in ketogenesis, was increased in rats fed trans-10, cis-12-CLA (Fig. 3(f)).

The sensitivity of palmitoyl-CoA oxidation towards malonyl-CoA was decreased after trans-10, cis-12-CLA feeding (Fig. 3(g)). In addition, the hepatic malonyl-CoA level was increased after trans-10, cis-12-CLA feeding (Fig. 3(h)), concomitant with a reduced activity of malonylCoA decarboxylase in liver (Fig. 3(i)).

Peroxisomal fatty acid oxidation in liver seemed also to be enhanced by trans-10, cis-12-CLA, as the hepatic activity of peroxisomal fatty acyl-CoA oxidase was increased more than twice in these rats (Fig. 3(j)).

Hepatic lipogenesis and TAG biosynthesis seemed to be unaffected by trans-10, cis-12-CLA feeding, as no changes were seen in mitochondrial and cytosolic acetyl-CoA carboxylase activity, in cytosolic fatty acid synthase activity, and in mitochondrial glycerol-3-phosphate acyl transferase in liver (data not shown).

Table 2. Liver weight and weight of epididymal white adipose tissue (eWAT), inguinal white adipose tissue (iWAT) and retroperitoneal white adipose tissue (rWAT) in obese Zucker fa/fa rats after $10 \mathrm{~d}$ feeding control or trans-10, cis-12-conjugated linoleic acid (CLA)*

(Mean values with their standard errors for six rats per group)

\begin{tabular}{|c|c|c|c|c|}
\hline & \multicolumn{2}{|c|}{ Control } & \multicolumn{2}{|c|}{$\begin{array}{c}\text { Trans-10, cis-12- } \\
\text { CLA }\end{array}$} \\
\hline & Mean & SEM & Mean & SEM \\
\hline Liver weight (\%) & $5 \cdot 17$ & 0.20 & $5 \cdot 28$ & 0.13 \\
\hline eWAT $(\%)$ & $2 \cdot 21$ & 0.08 & $2 \cdot 14$ & 0.14 \\
\hline iWAT (\%) & $5 \cdot 15$ & 0.19 & 4.79 & 0.22 \\
\hline rWAT (\%) & $1 \cdot 73$ & 0.06 & 1.65 & 0.10 \\
\hline
\end{tabular}

* Liver and WAT weights are expressed as a percentage of the body weight (hepatic index and adiposity). 
(a)
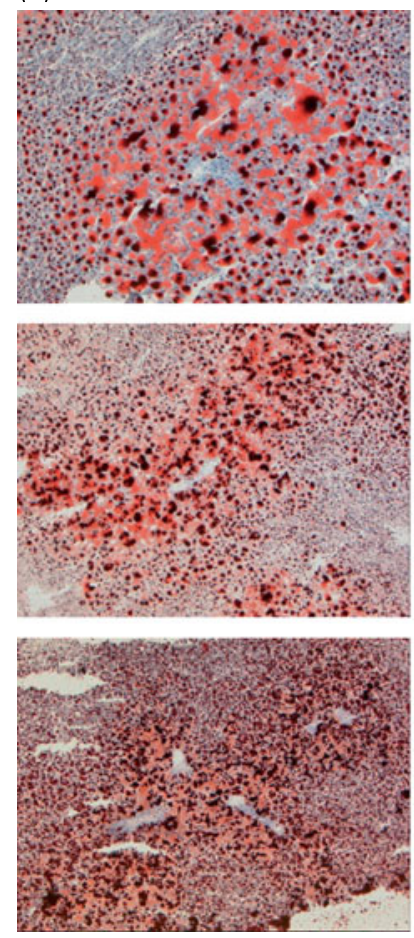
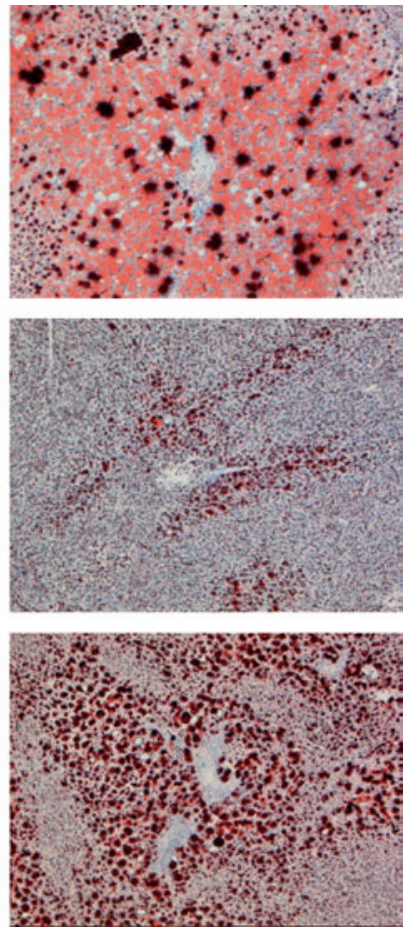

(b)
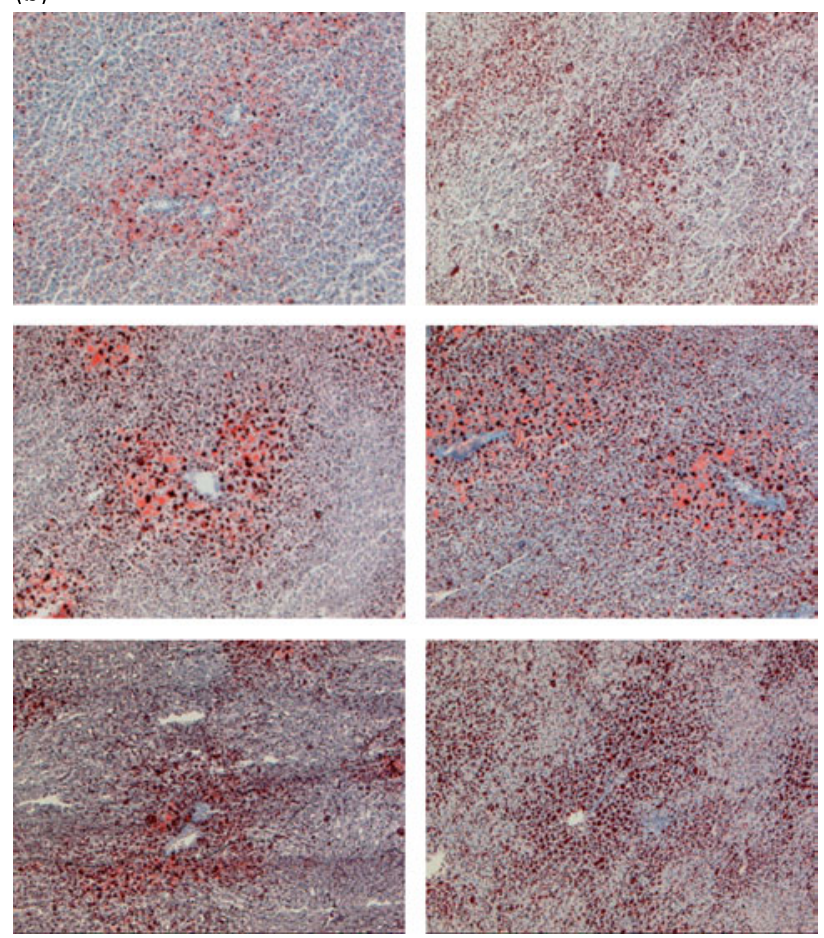

Fig. 2. Microphotographs of livers with a portal field in the centre stained with oil red $\mathrm{O}$ from obese Zucker rats fed a control diet (a) or a diet containing $1 \%$ trans-10, cis-12-conjugated linoleic acid (CLA) for $10 \mathrm{~d}(\mathrm{~b})$, showing one representative picture from each rat. Original magnification $\times 50$. The mean relative lipid amount (from staining) for the trans-10, cis-12-CLA group (9.3 (SEM 0.7)) was significantly different from that of the control group (26.8 (SEM 2.8) $(P<0.02)$ ). The mean liver TAG content for the trans-10, cis-12-CLA group (237 (SEM 19) $\mu \mathrm{mol} / \mathrm{g}$ liver) was significantly different from that of the control group (320 (SEM 23 ) $\mu \mathrm{mol} / \mathrm{g}$ liver $)(P<0.02)$

\section{Hepatic fatty acid composition}

Analysis of the liver lipids revealed that trans-10, cis-12-CLA was recovered in rats fed trans-10, cis-12-CLA, and comprised $0.45 \%$ of the fatty acids in the liver, whereas trans10, cis-12-CLA was not found in livers from the control rats (Table 3).

The total amount of SFA was not altered after trans-10, cis-12-CLA feeding, although the amount of 18:0 was nearly doubled (Table 3). The total amount of MUFA was significantly decreased in rats fed trans-10, cis-12-CLA, due to decreased amounts of the $\Delta 9$ desaturated fatty acids $16: 1 n-7$ and $18: 1 n-9$, thereby resulting in decreased $16: 1 n-7: 16: 0$ and $18: 1 n-9: 18: 0$ ratios (Table 3 ). The hepatic total level of PUFAs was increased after administration of trans-10, cis-12-CLA, mainly due to an increase in $n$-3 PUFA, but the levels of $20: 4 n-6,22: 4 n-6$ and $22: 5 n-6$ were also increased (Table 3 ). The $n-3$ PUFA: $n-6$ PUFA, $20: 4 n-6: 18: 2 n-6$ and $(20: 5 n-3+22: 6 n-3): 18: 3 n-3$ ratios in the liver were increased after trans-10, cis-12-CLA feeding (Table 3).

Uncoupling protein-2 and L-carnitine-palmitoyltransferase-I $m R N A$ levels in white adipose tissue depots

To investigate whether trans-10, cis-12-CLA could affect mitochondrial fatty acid $\beta$-oxidation and uncoupling in adipose tissue, the mRNA levels of the liver isoform of CPT-I (L-CPT-I) and UCP-2 in different WAT depots were measured. After trans-10, cis-12-CLA feeding, the mRNA level of UCP-2 was increased in eWAT and iWAT when compared with controls, but no change was seen in rWAT (Fig. 4). However, the L-CPT-I mRNA level in eWAT and iWAT was unaffected by trans-10, cis-12-CLA feeding, whereas the gene expression of L-CPT-I was increased in rWAT (Fig. 4).

White adipose tissue mRNA and plasma levels of adipokines

Although dietary trans-10, cis-12-CLA did not significantly affect the adipose tissue weights in the present experiment, it was of interest to evaluate whether the gene expressions of adipokines in WAT were affected, and whether the circulating amounts of cytokines were affected. Trans-10, cis-12-CLA increased the resistin mRNA levels in all white adipose depots studied (Fig. 5). In contrast, significantly lower mRNA levels of adiponectin were found in iWAT and rWAT, but not in eWAT, after trans-10, cis-12-CLA feeding (Fig. 5). Interestingly, trans-10, cis-12-CLA supplementation significantly reduced leptin mRNA levels in all WAT depots studied (Fig. 5), although no changes in leptin and adiponectin plasma concentrations were observed after trans-10, cis-12CLA feeding (Table 4).

\section{Plasma levels of lipids, glucose, insulin and C-peptide}

The plasma TAG level was markedly higher in rats fed trans-10, cis-12-CLA when compared with controls, whereas no significant differences were observed in plasma levels of NEFA, cholesterol and phospholipids (Table 4). 

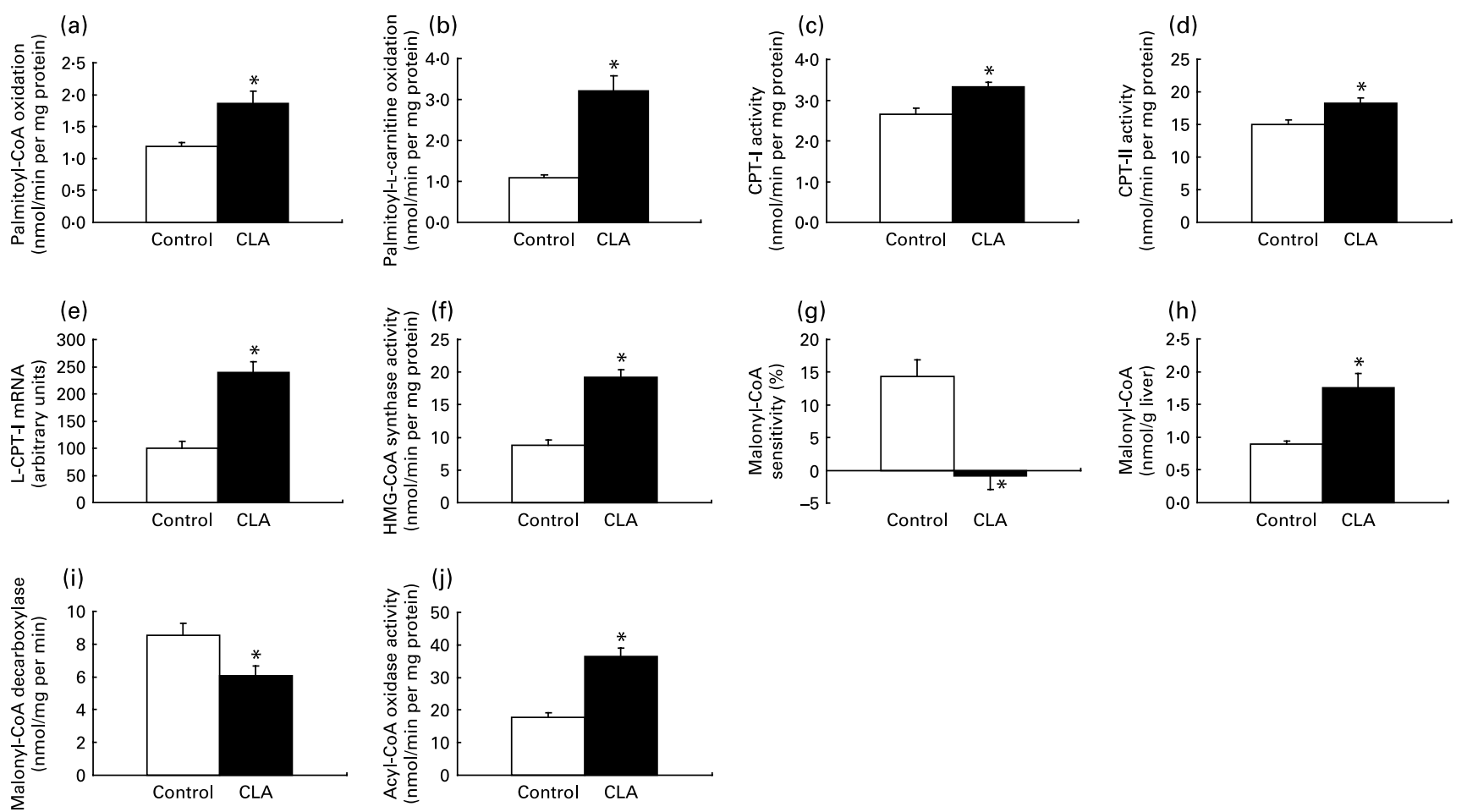

Fig. 3. The activity of mitochondrial $\beta$-oxidation using palmitoyl-CoA (a) or palmitoyl-L-carnitine (b) as substrate, the mitochondrial activities of carnitine palmitoyltransferase (CPT)-I (c) and CPT-II (d), the mRNA level of liver CPT-I (L-CPT-I) (e), the mitochondrial activity of 3-hydroxy-3-methylglutaryl (HMG)-CoA synthase (f), the malonyl-CoA sensitivity of palmitoyl-CoA oxidation (g), the malonyl-CoA concentration (h), the activity of malonyl-CoA decarboxylase (i) and the peroxisomal activity of fatty acyl CoA oxidase (j) in livers of obese Zucker rats fed a control diet or a diet containing $1 \%$ trans-10, cis-12-conjugated linoleic acid for $10 \mathrm{~d}$. Expression levels of CPT-I mRNA were analysed by RT-PCR and normalised to $\beta$-actin mRNA levels after densitometric analysis and expressed as a percentage of the control value. Values are means, with standard errors represented by vertical bars $(n 6)$. ${ }^{*}$ Mean value was significantly different from that of the control group $(P<0.05)$.

Administration of trans-10, cis-12-CLA did not significantly change the plasma levels of glucose, insulin and C-peptide (Table 4).

\section{Discussion}

The liver has been reported to be an important target for the effects of CLA on lipid metabolism. However, several published studies provide inconsistent results when comparing the effects of feeding different CLA isomers to different animal species. In an effort to penetrate these issues further, we examined the metabolic effects on liver and different adipose depots after feeding trans-10, cis-12-CLA since this isomer has been postulated to be the main mediator of CLA effects on body weight, adiposity and insulin resistance ${ }^{(8-11)}$. The data obtained indicated an inverse regulation by this isomer on hepatic and plasma TAG levels, and also an inverse regulation of adiponectin and resistin gene expression in several WAT depots.

In the present study, we found that trans-10, cis-12-CLA feeding reduced the hepatic TAG content. This finding is in contrast to several published studies showing that trans-10, cis-12-CLA feeding increases the hepatic TAG content in rats $^{(45)}$ and mice ${ }^{(46-49)}$. However, studies in rat models of obesity and insulin resistance have repeatedly demonstrated that feeding a CLA mixture containing mainly cis-9, trans11- and trans-10, cis-12-CLA markedly reduces the TAG content in the liver of such rats ${ }^{(50-53)}$. It has been debated whether trans-10, cis-12 feeding affects lipid metabolism, and although very few studies are performed using the pure trans-10, cis-12-CLA isomer, it has been reported that this CLA isomer increases the activities of CPT-I and CPT-II in mouse liver ${ }^{(54)}$, suggesting that fatty acid oxidation is increased. This is in line with the significant increase in mitochondrial $\beta$-oxidation, as well as increased activities of both CPT-I and CPT-II in liver and the increased hepatic mRNA level of CPT-I observed in the present study. The increased mitochondrial $\beta$-oxidation after trans-10, cis-12-CLA feeding was accompanied by an enhanced hepatic amount of malonylCoA, probably caused by the decreased activity of malonylCoA decarboxylase. Malonyl-CoA is a strong inhibitor of CPT-I and it seems that the increased mitochondrial $\beta$-oxidation observed in the present experiment could be a consequence of a lower sensitivity towards malonyl-CoA, since palmitoyl-CoA oxidation was less affected by malonyl-CoA inhibition after trans-10, cis-12-CLA feeding as compared with controls. Ketogenesis also appears to be increased, as the mitochondrial activity of HMG-CoA synthase was increased by trans-10, cis-12-CLA. In addition, the increased hepatic peroxisomal acyl-CoA oxidase activity suggested a higher capacity for oxidation of fatty acids in liver peroxisomes after trans-10, cis-12-CLA feeding. The increased hepatic fatty acid oxidation may be mediated via PPAR $\alpha$, since trans-10, cis-12-CLA is an activator of PPAR $\alpha^{(55,56)}$, although the relative liver weight was unchanged in the present experiment. However, the unchanged activities of the mitochondrial and cytosolic acetyl-CoA carboxylase 
Table 3. Selected fatty acids (wt\%) in livers from obese Zucker fa/fa rats after $10 \mathrm{~d}$ administration of control feed or $1 \%$ trans-10, cis-12-conjugated linoleic acid (CLA)

(Mean values with their standard errors for six rats per group)

\begin{tabular}{|c|c|c|c|c|}
\hline & \multicolumn{2}{|c|}{ Control } & \multicolumn{2}{|c|}{ Trans-10, cis-12-CLA } \\
\hline & Mean & SEM & Mean & SEM \\
\hline $14: 0$ & 1.71 & 0.07 & $1 \cdot 70$ & 0.12 \\
\hline $16: 0$ & 39.82 & 1.26 & 37.38 & 1.81 \\
\hline $18: 0$ & 6.40 & 0.39 & $10 \cdot 43^{*}$ & 0.52 \\
\hline $16: 1 n-9$ & 0.63 & 0.03 & 0.56 & 0.03 \\
\hline $16: 1 n-7$ & 6.85 & 0.45 & $3.99^{*}$ & 0.26 \\
\hline $18: 1 n-9$ & $25 \cdot 69$ & 0.81 & $21 \cdot 32^{*}$ & 0.98 \\
\hline $18: 1 n-7$ & 2.42 & 0.26 & 1.96 & 0.14 \\
\hline $18: 2 n-6$ & $9 \cdot 11$ & 0.42 & 8.29 & 0.45 \\
\hline $20: 2 n-6$ & 0.08 & 0.02 & 0.14 & 0.02 \\
\hline $18: 3 n-6$ & 0.38 & 0.04 & $0.24^{*}$ & 0.01 \\
\hline $20: 3 n-6$ & 0.33 & 0.05 & 0.43 & 0.04 \\
\hline $20: 4 n-6$ & 4.06 & 0.68 & $7 \cdot 01^{\star}$ & 0.92 \\
\hline $22: 4 n-6$ & 0.13 & 0.02 & $0.32^{*}$ & 0.05 \\
\hline $22: 5 n-6$ & 0.22 & 0.03 & $0.90^{*}$ & 0.16 \\
\hline $18: 3 n-3$ & 0.37 & 0.02 & 0.34 & 0.02 \\
\hline $20: 5 n-3$ & 0.14 & 0.03 & 0.13 & 0.01 \\
\hline $22: 5 n-3$ & 0.21 & 0.03 & $0.39^{*}$ & 0.07 \\
\hline $22: 6 n-3$ & 1.45 & 0.32 & $3.99^{*}$ & 0.59 \\
\hline Trans-10, cis-12-CLA & ND & & 0.45 & 0.03 \\
\hline SFA & 47.93 & 1.23 & 49.51 & 1.53 \\
\hline MUFA & 35.60 & $1 \cdot 16$ & $27 \cdot 84^{*}$ & 1.21 \\
\hline PUFA & $16 \cdot 47$ & 1.53 & $22 \cdot 65^{\star}$ & 2.07 \\
\hline$n-3$ PUFA & $2 \cdot 16$ & 0.38 & $4 \cdot 86^{\star}$ & 0.68 \\
\hline$n-6$ PUFA & 14.31 & 1.15 & $17 \cdot 35$ & 1.41 \\
\hline$n-3: n-6$ & 0.15 & 0.01 & $0.27^{\star}$ & 0.02 \\
\hline $16: 1 n-7: 16: 0$ & 0.17 & 0.01 & $0.11^{*}$ & 0.01 \\
\hline $18: 1 n-9: 18: 0$ & $4 \cdot 10$ & 0.34 & $2 \cdot 08^{*}$ & 0.19 \\
\hline $20: 4: 18: 2 \dagger$ & 0.44 & 0.11 & $0.84^{*}$ & 0.09 \\
\hline$(20: 5+22: 6): 18: 3 \ddagger$ & 4.25 & 0.61 & $11.93^{\star}$ & 1.41 \\
\hline
\end{tabular}

ND, not detected

*Mean value was significantly different from that of the control group $(P<0.05$; Student's $t$ test).

† 20:4n-6:18:2n-6 ratio

$\ddagger(20: 5 n-3+22: 6 n-3): 18: 3 n-3$ ratio.

activity, the cytosolic fatty acid synthase activity, and the mitochondrial glycerol-3-phosphate acyl transferase in the liver after trans-10, cis-12-CLA feeding implied that the reduced hepatic TAG content was not caused by decreased biosynthesis of fatty acids or TAG. Thus, dietary trans-10, cis-12-CLA seems to improve fatty liver in obese Zucker fa/fa rats by increasing the hepatic capacity for fatty acid $\beta$-oxidation.

The reduced $18: 1 n-9: 18: 0$ and $16: 1 n-7: 16: 0$ ratios in liver after trans-10, cis-12-CLA feeding suggested that the activity of stearoyl-CoA desaturase was decreased. This is in accordance with studies in liver microsomes from mice ${ }^{(57)}$ and rats ${ }^{(58)}$ showing that trans-10, cis-12-CLA inhibits the stearoyl-CoA desaturase activity. Studies in stearoyl-CoA desaturase-deficient mice show that they have a lower hepatic TAG content compared with wild-type mice, despite normal activity of glycerol phosphate acyltransferase ${ }^{(59)}$, an enzyme taking part in TAG synthesis. This is in line with the finding that glycerol phosphate acyltransferase activity was unchanged by trans-10, cis-12-CLA in the present study. In addition, since the activity of stearoyl-CoA desaturase is correlated with the secretion of TAG from hepatocytes ${ }^{(60)}$, trans-10, cis-12-CLA may improve fatty liver by reducing the stearoyl-CoA desaturase activity as proposed by Sebedio et al. ${ }^{(61)}$. Thus, a reduction in the stearoyl-CoA desaturase activity could, at least partially, explain the reduced hepatic content of TAG from rats fed trans-10, cis-12-CLA.

Feeding rats trans-10, cis-12-CLA also affected hepatic PUFA, as the $n-3: n-6,20: 4 n-6: 18: 2 n-6$ and $(20: 5 n-$ $3+20: 6 n-3): 18: 3 n-3$ ratios were increased. These are important findings since it has been shown that these ratios are reduced in the liver of patients with hepatic steatosis ${ }^{(62)}$. The increased product:precursor ratio of the $n-3$ and $n-6$ PUFA cascades suggests that the hepatic activities of $\Delta 5$ desaturase, $\Delta 6$ desaturase and elongase may have been enhanced by trans-10, cis-12-CLA feeding. The increased product:precursor ratios and the increased $n-3: n-6$ ratio favour $\beta$-oxidation over the synthesis of fatty acids and TAG, since long-chain PUFA, especially the $n-3$ PUFA, are activators of PPAR $\alpha^{(63)}$, and thus suggest that trans-10, cis-12-CLA may increase the hepatic $\beta$-oxidation via activation of PPAR $\alpha$.

The decreased hepatic TAG level in the trans-10, cis-12CLA group could be attributed to increased fatty acid oxidation in the liver. However, trans-10, cis-12-CLA feeding increased the plasma TAG level when compared with controls, in spite of the reduced TAG content in liver. These results suggest that there may be an imbalance between the hepatic TAG production and secretion, and the peripheral clearance by lipoprotein lipase. It has been reported that trans-10, cis12-CLA inhibits lipoprotein lipase activity in cultured 3T3L1 adipocytes $^{(64)}$ and in mouse adipose tissue ${ }^{(65)}$. Thus, the clearance of plasma lipoproteins could be reduced in Zucker $\mathrm{fa} / \mathrm{fa}$ rats in response to trans-10, cis-12-CLA feeding. In contrast to TAG, the plasma levels of NEFA, cholesterol and phospholipids in rats fed trans-10, cis-12-CLA were not statistically different from the control group. Hence, no hypolipidaemic effect was observed in our experiment in response to trans-10, cis-12-CLA, in agreement with some ${ }^{(20)}$ but in contrast to other ${ }^{(11)}$ reports, which reflects the controversy that exists concerning the specific effects of trans-10, cis-12-CLA.

We observed increased UCP-2 mRNA levels in response to trans-10, cis-12-CLA in some, but not all WAT depots. Although the precise role of UCP-2 in the regulation of energy expenditure is still unclear, our and others' findings ${ }^{(9,18,20)}$ suggest that increased UCP-2 levels may be one of the mechanisms by which trans-10, cis-12-CLA could reduce adiposity and body weight. We found a significant increase in L-CPT-I mRNA levels in rWAT, possibly mediated via PPAR $\alpha^{(55,56)}$, but not in eWAT and iWAT. The UCP-2 mRNA level was increased in eWAT and iWAT, but was not affected in rWAT after trans-10, cis-12CLA feeding, which may suggest that UCP-2 and CPT-I are regulatory coupled in the control of fatty acid oxidation. The enhanced potential for fatty acid oxidation in these adipose depots was not accompanied with a decrease in WAT mass, and a longer period of dietary supplementation with this isomer may be required to obtain a statistically significant decrease in adipose tissue mass.

In the present study, trans-10, cis-12-CLA feeding reduced the leptin mRNA levels in all white adipose depots studied, especially in visceral depots (eWAT and rWAT), confirming previous results obtained in brown adipose tissue ${ }^{(6)}$. The reduced leptin mRNA levels were not a consequence of reduced adiposity, which was not statistically significant in our experiment, but could be due to a direct effect of 

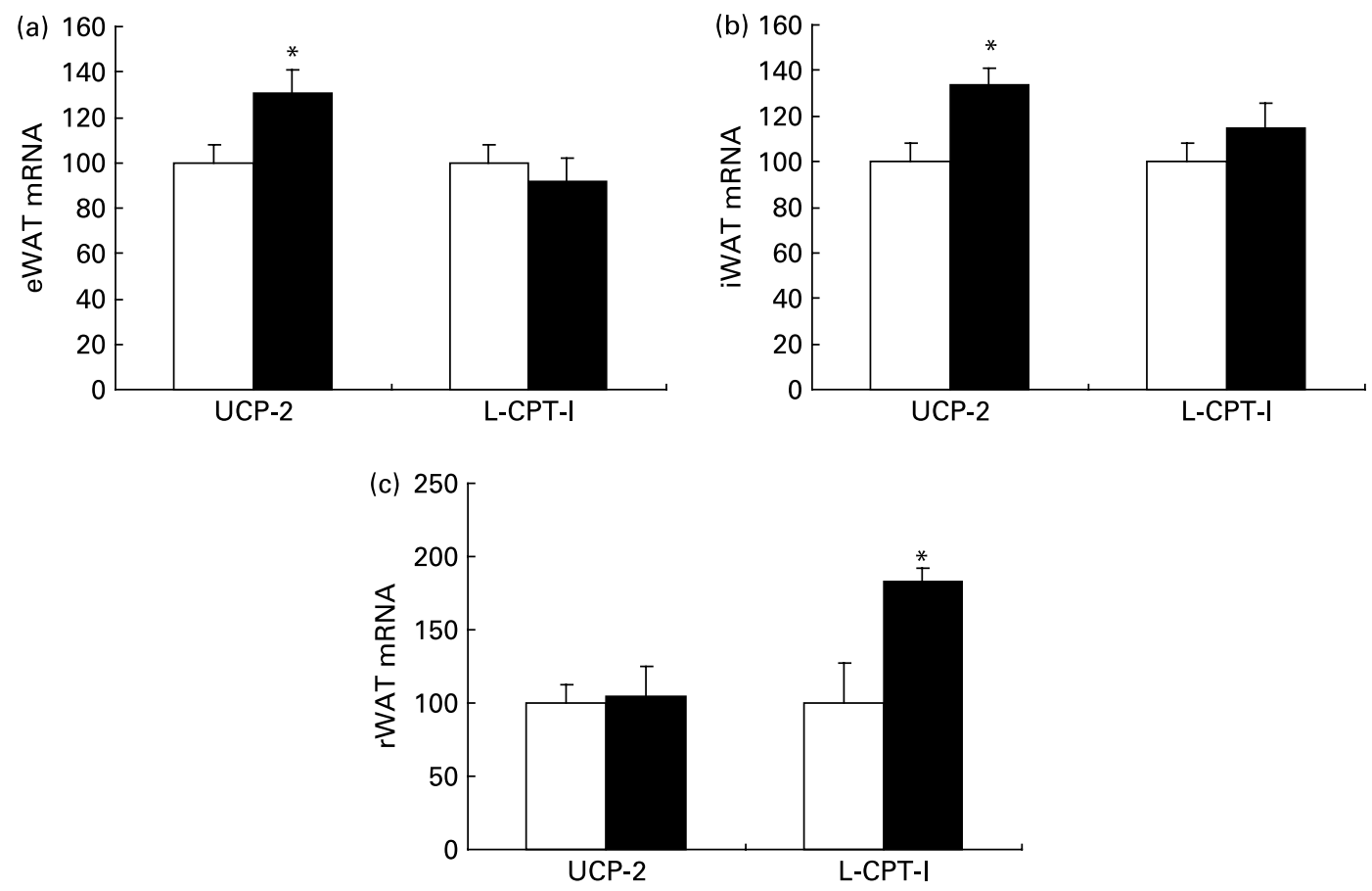

Fig. 4. The mRNA levels of uncoupling protein (UCP)-2 and liver carnitine palmitoyltransferase (L-CPT)-I in epididymal white adipose tissue (eWAT) (a), inguinal white adipose tissue (iWAT) (b) and retroperitoneal white adipose tissue (rWAT) (c) from obese Zucker rats fed a control diet ( $\square$ ) or a diet containing $1 \%$ trans-10, cis-12-conjugated linoleic acid (ם) for $10 \mathrm{~d}$. Expression levels of the specific mRNA were analysed by Northern blotting (UCP-2) or RT-PCR (L-CPT-I) and normalised to 18S rRNA (Northern blotting) levels or $\beta$-actin mRNA (RT-PCR) levels after densitometric analysis and expressed as a percentage of the control value. Values are means, with standard errors represented by vertical bars ( $n$ 6). ${ }^{*}$ Mean value was significantly different from that of the control group $(P<0.05)$.
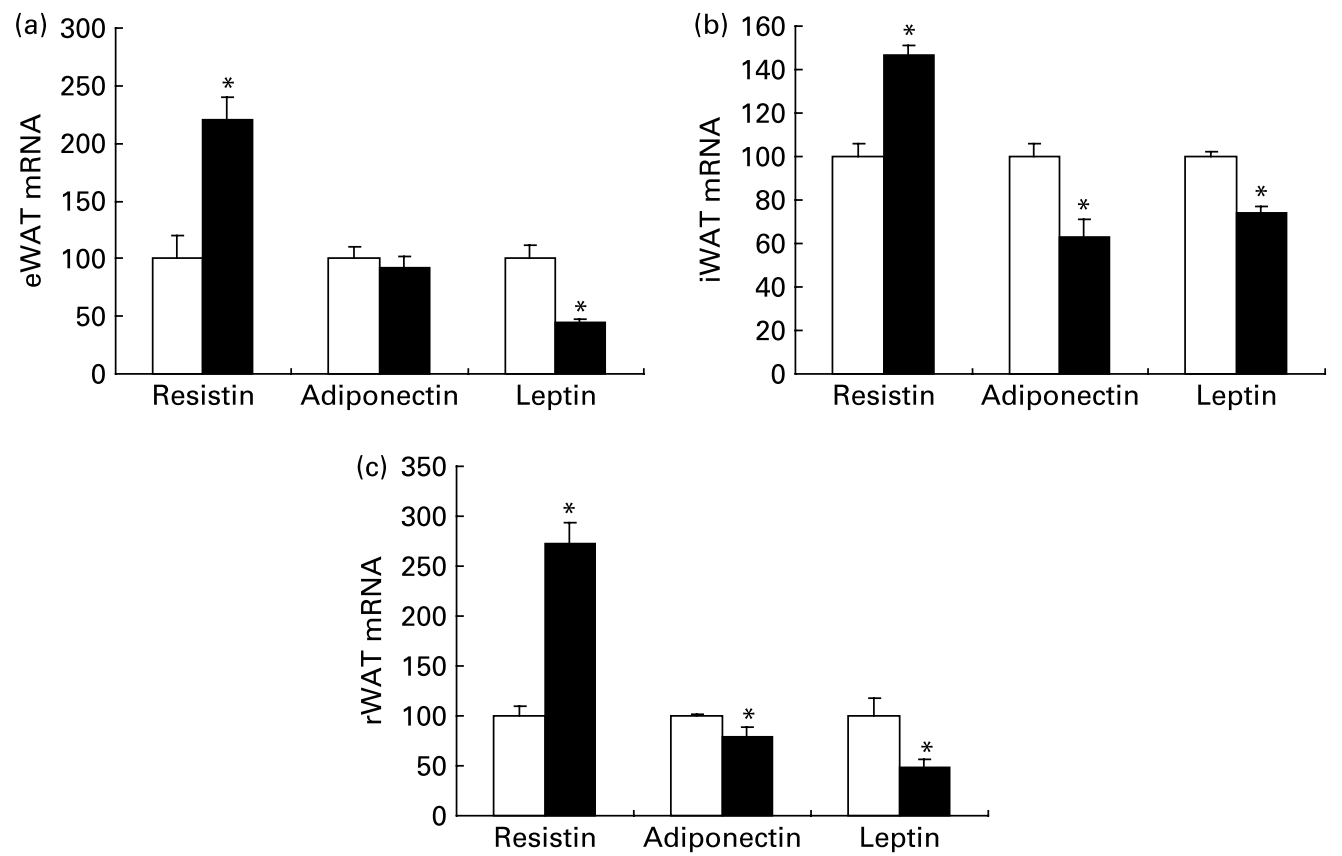

Fig. 5. The mRNA levels of resistin, adiponectin and leptin in epididymal white adipose tissue (eWAT) (a), inguinal white adipose tissue (iWAT) (b) and retroperitoneal white adipose tissue (rWAT) (c) from obese Zucker rats fed a control diet ( $\square$ ) or a diet containing $1 \%$ trans-10, cis-12-conjugated linoleic acid ( $\square$ ) for $10 \mathrm{~d}$. Expression levels of the specific mRNA were analysed by Northern blotting (resistin and leptin) or RT-PCR (adiponectin) and normalised to 18S rRNA (Northern blotting) or $\beta$-actin mRNA (RT-PCR) after densitometric analysis and finally expressed as a percentage of the control value. Values are means, with standard errors represented by vertical bars $(n 6)$. ${ }^{\star}$ Mean value was significantly different from that of the control group $(P<0.05)$. 
Table 4. Leptin, adiponectin, glucose, insulin, C-peptide and lipids in plasma from obese Zucker fa/fa rats after $10 \mathrm{~d}$ administration of control feed or $1 \%$ trans-10, cis-12-conjugated linoleic acid (CLA)

(Mean values with their standard errors for six rats per group)

\begin{tabular}{lcccccc}
\hline & \multicolumn{2}{c}{ Control } & & \multicolumn{2}{c}{ Trans-10, cis-12-CLA } \\
\cline { 2 - 3 } & Mean & SEM & & Mean & SEM \\
\hline Leptin $(\mathrm{ng} / \mathrm{ml})$ & 24.0 & 1.3 & & 23.3 & 1.5 \\
Adiponectin $(\mu \mathrm{g} / \mathrm{ml})$ & 16.3 & 0.7 & & 14.0 & 1.5 \\
Glucose $(\mathrm{mm})$ & 8.80 & 0.91 & & 8.37 & 0.59 \\
Insulin $(\mathrm{ng} / \mathrm{ml})$ & 3.0 & 1.4 & & 4.2 & 0.9 \\
C-peptide $(\mathrm{pm})$ & 802 & 177 & & 1203 & 127 \\
TAG (mM) & 1.67 & 0.07 & & $2.73^{*}$ & 0.43 \\
NEFA (mM) & 0.59 & 0.11 & & 0.77 & 0.12 \\
Cholesterol (mM) & 4.16 & 0.27 & & 3.78 & 0.29 \\
Phospholipids (mM) & 3.71 & 0.21 & & 4.02 & 0.41 \\
\hline
\end{tabular}

*Mean value was significantly different from that of the control group $(P<0.05$; Student's $t$ test).

trans-10, cis-12-CLA on gene expression, as suggested by Yamasaki et al. ${ }^{(66)}$. However, since trans-10, cis-12-CLA is demonstrated to bind and activate PPAR $\gamma^{(56)}$, and PPAR $\gamma$ activators are demonstrated to reduce the gene expression of leptin in rodents ${ }^{(67)}$, the reduced leptin mRNA level in WAT may be due to the stimulation of PPAR $\gamma$. Despite the reduction of leptin mRNA levels in adipose tissues, no significant change was found in plasma leptin levels in trans-10, cis12-CLA-fed rats when compared with controls.

It has been reported that a mixture of CLA isomers improves glucose tolerance and insulin resistance in rodents $^{(9,68)}$, but this has been difficult to reproduce in human studies ${ }^{(21)}$. Elevated plasma resistin levels may cause insulin resistance ${ }^{(25)}$, whereas an increased adiponectin level promotes fatty acid oxidation in muscle and inhibits hepatic gluconeogenesis, resulting in reduced plasma concentrations of NEFA, TAG and glucose ${ }^{(27-29)}$. Our data showed no effect of trans-10, cis-12-CLA on plasma concentrations of glucose and insulin, but an increased resistin mRNA level was found in all WAT depots studied whereas the adiponectin mRNA level was reduced in the same depots except for eWAT. This effect on adiponectin is consistent with the reduced adiponectin mRNA level found in rWAT from mice in response to trans-10, cis-12-CLA feeding $^{(49)}$. Nevertheless, plasma adiponectin levels were not significantly affected in our study, which can be due to the short period of supplementation in the present experiment $(10 \mathrm{~d})$. Studies in mice reveal that a marked reduction in the circulating levels of adiponectin and leptin could precede and induce a peripheral insulin resistance and hyperinsulinaemia after supplementation with trans-10, cis-12-CLA $^{(69)}$. It has been proposed that CLA-induced insulin resistance could be due, at least in part, to leptin depletion, because leptin infusion in CLA-fed mice may restore leptin and insulin plasma levels ${ }^{(18)}$. Thus, although we did not measure insulin sensitivity directly, our data on the expression of adipokines after feeding trans-10, cis-12-CLA in WAT are consistent with impaired insulin sensitivity reported by others $^{(18,20,21)}$.

Feed intake was lower in rats fed the diet containing $1 \%$ trans-10, cis-12-CLA, but the reported metabolic effects in the present experiment are probably not solely due to the lower intake. Since the feed intake was similar for the trans-10, cis-12-CLA group and the control group during the first $2 \mathrm{~d}$ of the experiment, trans-10, cis-12-CLA probably did not affect feed taste but might instead induce an effect on appetite or energy requirement after a few days. Food deprivation may increase hepatic $\beta$-oxidation ${ }^{(70)}$ by reducing the malonyl-CoA concentration ${ }^{(71)}$ and inhibit fatty acid synthesis ${ }^{(70)}$. In the present experiment, however, trans-10, cis-12-CLA feeding enhanced the level of malonyl-CoA and increased $\beta$-oxidation in the liver, the latter probably due to a reduced malonyl-CoA sensitivity of CPT-I. In addition, the activities of rate-limiting enzymes involved in fatty acid synthesis were not affected by trans-10, cis-12-CLA. However, due to the reduced feed intake among rats fed trans-10, cis-12-CLA it is not possible to distinguish the effects of reduced energy supply and metabolic changes due to the intake of trans-10, cis-12-CLA. Thus, some of the effects of CLA feeding might be due to low energy intake among the rats fed trans-10, cis-12-CLA as compared with the controls. However, no difference was seen in body weight between the trans-10, cis-12-CLA-fed rats and the control rats. In addition, no differences were seen at the level of adipose tissue depot mass (adiposity) between the groups, corroborating with the unchanged plasma levels of NEFA. A lack of effect of CLA in reducing adiposity was previously reported in obese male Zucker rats fed a CLA mixture for 5 weeks ${ }^{(72)}$, although Henriksen et al. found a decreased body weight after $21 \mathrm{~d}$ treatment of obese female Zucker rats with trans-10, cis-12-CLA $^{(11)}$.

Little is known about the effect of the trans-10, cis-12 isomer of CLA on $\mathrm{O}_{2}$ consumption, and $\mathrm{CO}_{2}$ and heat production in obese Zucker rats. However, studies on female Sprague-Dawley rats fed a mixture of CLA isomers (mainly cis-9, trans-11- and trans-10, cis-12-CLA) for $7 \mathrm{~d}$ showed no effect on feed intake, growth, $\mathrm{O}_{2}$ consumption, $\mathrm{CO}_{2}$ or heat production ${ }^{(73)}$. A study with mice fed a mixture of cis-9, trans-11- and trans-10, cis-12-CLA, on the other hand, showed a reduced energy intake and growth rate, and an increased metabolic rate and decreased night-time respiratory quotient (RQ), with no overall effect on RQ measured over $24 \mathrm{~h}^{(14)}$. The effect of the trans-10, cis-12 isomer of CLA on the RQ deserves further investigation to learn more about the relationship between energy intake and the effects on lipid metabolism after feeding this isomer.

In summary, the present results provide new evidence suggesting that dietary supplementation with trans-10, cis12-CLA may change the expression of key genes involved in lipid metabolism in adipose tissues as well as key enzymes of fatty acid oxidation in the liver of Zucker fa/fa rats, resulting in an increased catabolism of lipids. The liver TAG content was reduced without improving overall adiposity, but rather by increasing fatty acid oxidation and reducing the malonyl-CoA sensitivity of CPT-I. Moreover, our data suggest that this CLA isomer modulates the expression of resistin and adiponectin inversely in adipose tissues. The reduced level of leptin mRNA and the increased level of resistin mRNA in WAT also suggest that insulin sensitivity was impaired after trans-10, cis-12-CLA feeding. Hence, the present results suggest that trans-10, cis-12-CLA may have some beneficial effects on lipid metabolism but possibly reduces insulin sensitivity. This aspect raises the importance 
of more detailed studies to evaluate the effects of trans-10, cis-12-CLA and the safety of using CLA for weight management.

\section{Acknowledgements}

The present study was supported by the Spanish Government (SAF 2001-4859E, BFI 2000-0988-C06 and FIS 01-1379), by the European Union (QLK1-2001-00183) and by the Norwegian Research Council.

E. R. was the recipient of a doctoral fellowship from the Spanish Government (Ministerio de Educación, Cultura y Deportes).

O. A. G., E. R., H. W., J. S., A. P. and R. K. B. designed the study. O. A. G., E. R. and H. W. performed the animal experiment, and analysed and interpreted the data. S. M. performed the oil red $\mathrm{O}$ staining of the livers and J. E. R. performed the analysis of the plasma leptin, adiponectin and insulin levels. A. P. and R. K. B. supervised the experiment, obtained funding and provided administrative, technical, and material support. O. A. G. and E. R. wrote the draft of the manuscript; all authors critically reviewed the manuscript. O. A. G. and E. $R$ contributed equally to the present study.

We declare that there are no conflicts of interest regarding this paper.

\section{References}

1. Wahle KW, Heys SD \& Rotondo D (2004) Conjugated linoleic acids: are they beneficial or detrimental to health? Prog Lipid Res 43, 553-587.

2. Dhiman TR, Nam SH \& Ure AL (2005) Factors affecting conjugated linoleic acid content in milk and meat. Crit Rev Food Sci Nutr 45, 463-482.

3. Yurawecz MP, Roach JA, Sehat N, et al. (1998) A new conjugated linoleic acid isomer, 7 trans, 9 cis-octadecadienoic acid, in cow milk, cheese, beef and human milk and adipose tissue. Lipids 33, 803-809.

4. Sehat N, Kramer JK, Mossoba MM, et al. (1998) Identification of conjugated linoleic acid isomers in cheese by gas chromatography, silver ion high performance liquid chromatography and mass spectral reconstructed ion profiles. Comparison of chromatographic elution sequences. Lipids 33, 963-971.

5. Evans M, Brown J \& McIntosh M (2002) Isomer-specific effects of conjugated linoleic acid (CLA) on adiposity and lipid metabolism. J Nutr Biochem 13, 508-516.

6. Rodriguez E, Ribot J \& Palou A (2002) Trans-10, cis-12, but not cis-9, trans-11 CLA isomer, inhibits brown adipocyte thermogenic capacity. Am J Physiol Regul Integr Comp Physiol 282, R1789-R1797.

7. Tricon S, Burdge GC, Kew S, et al. (2004) Opposing effects of cis-9,trans-11 and trans-10,cis-12 conjugated linoleic acid on blood lipids in healthy humans. Am J Clin Nutr 80, 614-620.

8. Park Y, Storkson JM, Albright KJ, et al. (1999) Evidence that the trans-10,cis-12 isomer of conjugated linoleic acid induces body composition changes in mice. Lipids 34, 235-241.

9. Ryder JW, Portocarrero CP, Song XM, et al. (2001) Isomerspecific antidiabetic properties of conjugated linoleic acid. Improved glucose tolerance, skeletal muscle insulin action, and UCP-2 gene expression. Diabetes 50, 1149-1157.

10. Hargrave KM, Li C, Meyer BJ, et al. (2002) Adipose depletion and apoptosis induced by trans-10, cis-12 conjugated linoleic acid in mice. Obes Res 10, 1284-1290.
11. Henriksen EJ, Teachey MK, Taylor ZC, et al. (2003) Isomerspecific actions of conjugated linoleic acid on muscle glucose transport in the obese Zucker rat. Am J Physiol Endocrinol Metab 285, E98-E105.

12. Park Y, Albright KJ, Storkson JM, et al. (1999) Changes in body composition in mice during feeding and withdrawal of conjugated linoleic acid. Lipids 34, 243-248.

13. Evans M, Lin X, Odle J, et al. (2002) Trans-10, cis-12 conjugated linoleic acid increases fatty acid oxidation in 3T3-L1 preadipocytes. J Nutr 132, 450-455.

14. West DB, Delany JP, Camet PM, et al. (1998) Effects of conjugated linoleic acid on body fat and energy metabolism in the mouse. Am J Physiol 275, R667-R672.

15. Brown JM, Halvorsen YD, Lea-Currie YR, et al. (2001) Trans10, cis-12, but not cis-9, trans-11, conjugated linoleic acid attenuates lipogenesis in primary cultures of stromal vascular cells from human adipose tissue. J Nutr 131, 2316-2321.

16. Kang K, Liu W, Albright KJ, et al. (2003) Trans-10,cis-12 CLA inhibits differentiation of 3T3-L1 adipocytes and decreases PPAR $\gamma$ expression. Biochem Biophys Res Commun 303, 795-799.

17. West DB, Blohm FY, Truett AA, et al. (2000) Conjugated linoleic acid persistently increases total energy expenditure in AKR/ $\mathrm{J}$ mice without increasing uncoupling protein gene expression. J Nutr 130, 2471-2477.

18. Tsuboyama-Kasaoka N, Takahashi M, Tanemura $\mathrm{K}$, et al. (2000) Conjugated linoleic acid supplementation reduces adipose tissue by apoptosis and develops lipodystrophy in mice. Diabetes 49, 1534-1542.

19. Choi JS, Jung MH, Park HS, et al. (2004) Effect of conjugated linoleic acid isomers on insulin resistance and mRNA levels of genes regulating energy metabolism in high-fat-fed rats. Nutrition 20, 1008-1017.

20. Roche HM, Noone E, Sewter C, et al. (2002) Isomer-dependent metabolic effects of conjugated linoleic acid: insights from molecular markers sterol regulatory element-binding protein-1c and LXR $\alpha$. Diabetes 51, 2037-2044.

21. Riserus U, Arner P, Brismar K, et al. (2002) Treatment with dietary trans 10 , cis 12 conjugated linoleic acid causes isomerspecific insulin resistance in obese men with the metabolic syndrome. Diabetes Care 25, 1516-1521.

22. Steppan CM \& Lazar MA (2002) Resistin and obesity-associated insulin resistance. Trends Endocrinol Metab 13, 18-23.

23. Tsao TS, Lodish HF \& Fruebis J (2002) ACRP30, a new hormone controlling fat and glucose metabolism. Eur J Pharmacol 440, 213-221.

24. Statnick MA, Beavers LS, Conner LJ, et al. (2000) Decreased expression of apM1 in omental and subcutaneous adipose tissue of humans with type 2 diabetes. Int $J$ Exp Diabetes Res 1, 81-88.

25. Steppan CM, Bailey ST, Bhat S, et al. (2001) The hormone resistin links obesity to diabetes. Nature 409, 307-312.

26. Li J, Yu X, Pan W, et al. (2002) Gene expression profile of rat adipose tissue at the onset of high-fat-diet obesity. Am J Physiol Endocrinol Metab 282, E1334-E1341.

27. Berg AH, Combs TP, Du X, et al. (2001) The adipocytesecreted protein Acrp30 enhances hepatic insulin action. Nat Med 7, 947-953.

28. Fruebis J, Tsao TS, Javorschi S, et al. (2001) Proteolytic cleavage product of $30-\mathrm{kDa}$ adipocyte complement-related protein increases fatty acid oxidation in muscle and causes weight loss in mice. Proc Natl Acad Sci U S A 98, 2005-2010.

29. Holst D \& Grimaldi PA (2002) New factors in the regulation of adipose differentiation and metabolism. Curr Opin Lipidol 13, 241-245.

30. Berge RK, Flatmark T \& Osmundsen H (1984) Enhancement of long-chain acyl-CoA hydrolase activity in peroxisomes and 
mitochondria of rat liver by peroxisomal proliferators. Eur $J$ Biochem 141, 637-644.

31. Willumsen N, Hexeberg S, Skorve J, et al. (1993) Docosahexaenoic acid shows no triglyceride-lowering effects but increases the peroxisomal fatty acid oxidation in liver of rats. J Lipid Res 34, 13-22.

32. Madsen L, Froyland L, Dyroy E, et al. (1998) Docosahexaenoic and eicosapentaenoic acids are differently metabolized in rat liver during mitochondria and peroxisome proliferation. $J$ Lipid Res 39, 583-593.

33. Alam N \& Saggerson ED (1998) Malonyl-CoA and the regulation of fatty acid oxidation in soleus muscle. Biochem $J$ 334, 233-241.

34. Small GM, Burdett K \& Connock MJ (1985) A sensitive spectrophotometric assay for peroxisomal acyl-CoA oxidase. Biochem J 227, 205-210.

35. Clinkenbeard KD, Reed WD, Mooney RA, et al. (1975) Intracellular localization of the 3-hydroxy-3-methylglutaryl coenzyme A cycle enzymes in liver. Separate cytoplasmic and mitochondrial 3-hydroxy-3-methylglutaryl coenzyme A generating systems for cholesterogenesis and ketogenesis. $J$ Biol Chem 250, $3108-3116$

36. Tanabe T, Nakanishi S, Hashimoto T, et al. (1981) Acetyl-CoA carboxylase from rat liver. Methods Enzymol 71, 5-16.

37. Roncari DA (1981) Fatty acid synthase from human liver. Methods Enzymol 71, 73-79.

38. Skorve J, al-Shurbaji A, Asiedu D, et al. (1993) On the mechanism of the hypolipidemic effect of sulfur-substituted hexadecanedioic acid (3-thiadicarboxylic acid) in normolipidemic rats. J Lipid Res 34, 1177-1185.

39. Bates EJ \& Saggerson D (1977) A selective decrease in mitochondrial glycerol phosphate acyltransferase activity in livers from streptozotocin-diabetic rats. FEBS Lett 84, 229-232.

40. Wergedahl H, Liaset B, Gudbrandsen OA, et al. (2004) Fish protein hydrolysate reduces plasma total cholesterol, increases the proportion of HDL cholesterol, and lowers acyl-CoA:cholesterol acyltransferase activity in liver of Zucker rats. J Nutr 134, $1320-1327$.

41. Bligh EG \& Dyer WJ (1959) A rapid method of total lipid extraction and purification. Can J Biochem Physiol 37, 911-917.

42. Ribot J, Felipe F, Bonet ML, et al. (2001) Changes of adiposity in response to vitamin A status correlate with changes of PPAR $\gamma 2$ expression. Obes Res 9, 500-509.

43. Jacobsson A, Stadler U, Glotzer MA, et al. (1985) Mitochondrial uncoupling protein from mouse brown fat. Molecular cloning, genetic mapping, and mRNA expression. J Biol Chem 260, 16250-16254.

44. Trayhurn P, Duncan JS, Nestor A, et al. (1994) Chemiluminescent detection of mRNAs on Northern blots with digoxigenin end-labeled oligonucleotides. Anal Biochem 222, 224-230.

45. Sanders SR, Teachey MK, Ptock A, et al. (2004) Effects of specific conjugated linoleic acid isomers on growth characteristics in obese Zucker rats. Lipids 39, 537-543.

46. Clement L, Poirier H, Niot I, et al. (2002) Dietary trans-10, cis12 conjugated linoleic acid induces hyperinsulinemia and fatty liver in the mouse. J Lipid Res 43, 1400-1409.

47. Kelley DS, Bartolini GL, Warren JM, et al. (2004) Contrasting effects of t10,c12- and c9,t11-conjugated linoleic acid isomers on the fatty acid profiles of mouse liver lipids. Lipids 39, $135-141$.

48. Degrace P, Demizieux L, Gresti J, et al. (2003) Association of liver steatosis with lipid oversecretion and hypotriglyceridaemia in C57BL/6j mice fed trans-10,cis-12-linoleic acid. FEBS Lett 546, 335-339.

49. Warren JM, Simon VA, Bartolini G, et al. (2003) Trans-10,cis12 CLA increases liver and decreases adipose tissue lipids in mice: possible roles of specific lipid metabolism genes. Lipids 38, 497-504.

50. Rahman SM, Huda MN, Uddin MN, et al. (2002) Short-term administration of conjugated linoleic acid reduces liver triglyceride concentration and phosphatidate phosphohydrolase activity in OLETF rats. J Biochem Mol Biol 35, 494-497.

51. Wang Y-M, Rahman SM, Nagao K, et al. (2003) Conjugated linoleic acid reduces hepatic microsomal triacylglycerol transfer protein activity and hepatic triacylglycerol mass in obese rats. J Oleo Sci 52, 129-134.

52. Nagao K, Inoue N, Wang YM, et al. (2005) Dietary conjugated linoleic acid alleviates nonalcoholic fatty liver disease in Zucker (fa/fa) rats. $J$ Nutr 135, 9-13.

53. Noto A, Zahradka P, Yurkova N, et al. (2006) Conjugated linoleic acid reduces hepatic steatosis, improves liver function, and favorably modifies lipid metabolism in obese insulin-resistant rats. Lipids 41, 179-188.

54. Degrace P, Demizieux L, Gresti J, et al. (2004) Hepatic steatosis is not due to impaired fatty acid oxidation capacities in C57BL/ $6 \mathrm{~J}$ mice fed the conjugated trans-10,cis-12-isomer of linoleic acid. $J$ Nutr 134, 861-867.

55. Moya-Camarena SY, Vanden Heuvel JP, Blanchard SG, et al. (1999) Conjugated linoleic acid is a potent naturally occurring ligand and activator of PPAR $\alpha$. J Lipid Res 40, 1426-1433.

56. Belury MA, Moya-Camarena SY, Lu M, et al. (2002) Conjugated linoleic acid is an activator and ligand for peroxisome proliferator-activated receptor- $\gamma$ (PPAR $\gamma$ ). Nutr Res 22, 817-824.

57. Park Y, Storkson JM, Ntambi JM, et al. (2000) Inhibition of hepatic stearoyl-CoA desaturase activity by trans-10, cis-12 conjugated linoleic acid and its derivatives. Biochim Biophys Acta 1486, 285-292.

58. Bretillon L, Chardigny JM, Gregoire S, et al. (1999) Effects of conjugated linoleic acid isomers on the hepatic microsomal desaturation activities in vitro. Lipids 34, 965-969.

59. Miyazaki M, Kim YC, Gray-Keller MP, et al. (2000) The biosynthesis of hepatic cholesterol esters and triglycerides is impaired in mice with a disruption of the gene for stearoylCoA desaturase 1. J Biol Chem 275, 30132-30138.

60. Legrand P, Catheline D, Fichot MC, et al. (1997) Inhibiting $\Delta 9$ desaturase activity impairs triacylglycerol secretion in cultured chicken hepatocytes. J Nutr 127, 249-256.

61. Sebedio JL, Angioni E, Chardigny JM, et al. (2001) The effect of conjugated linoleic acid isomers on fatty acid profiles of liver and adipose tissues and their conversion to isomers of $16: 2$ and $18: 3$ conjugated fatty acids in rats. Lipids 36, 575-582.

62. Videla LA, Rodrigo R, Araya J, et al. (2004) Oxidative stress and depletion of hepatic long-chain polyunsaturated fatty acids may contribute to nonalcoholic fatty liver disease. Free Radic Biol Med 37, 1499-1507.

63. Clarke SD (2001) Polyunsaturated fatty acid regulation of gene transcription: a molecular mechanism to improve the metabolic syndrome. J Nutr 131, 1129-1132.

64. Lin Y, Kreeft A, Schuurbiers JA, et al. (2001) Different effects of conjugated linoleic acid isomers on lipoprotein lipase activity in 3T3-L1 adipocytes. J Nutr Biochem 12, 183-189.

65. Xu X, Storkson J, Kim S, et al. (2003) Short-term intake of conjugated linoleic acid inhibits lipoprotein lipase and glucose metabolism but does not enhance lipolysis in mouse adipose tissue. J Nutr 133, 663-667.

66. Yamasaki M, Ikeda A, Oji M, et al. (2003) Modulation of body fat and serum leptin levels by dietary conjugated linoleic acid in Sprague-Dawley rats fed various fat-level diets. Nutrition 19, 30-35.

67. De Vos P, Lefebvre AM, Miller SG, et al. (1996) Thiazolidinediones repress ob gene expression in rodents via activation of peroxisome proliferator-activated receptor $\gamma . J$ Clin Invest $\mathbf{9 8}$, 1004-1009. 
68. Nagao K, Inoue N, Wang YM, et al. (2003) Conjugated linoleic acid enhances plasma adiponectin level and alleviates hyperinsulinemia and hypertension in Zucker diabetic fatty (fa/fa) rats. Biochem Biophys Res Commun 310, 562-566.

69. Poirier H, Rouault C, Clement L, et al. (2005) Hyperinsulinaemia triggered by dietary conjugated linoleic acid is associated with a decrease in leptin and adiponectin plasma levels and pancreatic $\beta$ cell hyperplasia in the mouse. Diabetologia $\mathbf{4 8}$, $1059-1065$.

70. Boyd ME, Albright EB, Foster DW, et al. (1981) In vitro reversal of the fasting state of liver metabolism in the rat.
Reevaluation of the roles of insulin and glucose. J Clin Invest 68, $142-152$.

71. McGarry JD (2001) Travels with carnitine palmitoyltransferase I: from liver to germ cell with stops in between. Biochem Soc Trans 29, 241-245.

72. Sisk MB, Hausman DB, Martin RJ, et al. (2001) Dietary conjugated linoleic acid reduces adiposity in lean but not obese Zucker rats. J Nutr 131, 1668-1674.

73. Azain MJ, Hausman DB, Sisk MB, et al. (2000) Dietary conjugated linoleic acid reduces rat adipose tissue cell size rather than cell number. J Nutr 130, 1548-1554. 